\section{Kapnometrie, transkutane}

Helga Peter

Marburg, Deutschland

\section{Englischer Begriff}

transcutaneous capnometry

\section{Definition}

Transkutane Messung des arteriellen Kohlendioxidgehaltes. Siehe auch

- „Atmungsmessung“

- „Kardiorespiratorische Polysomnographie“ 